\title{
Quality Learning Spaces, Resources, Technologies and Constructive Alignment Element in Teaching and Learning
}

Azwani Masuwai

Fakulti Pembangunan Manusia, Universiti Pendidikan Sultan Idris, 35900 Tanjung Malim, Malaysia

*Corresponding author: m20132002450@siswa.upsi.edu.my

Article history: Received:24 July 2017 Received in revised form: 07 November 2018 Accepted: 31 November 2018 Published online: 31 December 2018

\begin{abstract}
The purpose of this study is to explore the importance of quality learning spaces and constructive alignment in teaching and learning. The study established by using Teaching and Learning Guiding Principles Instrument (TLGPI) to look out the reliability and validity of the instrument in generating teaching and learning guiding principles (TLGP). Participants consisted of 357 Malaysian teacher educators from ten Malaysian higher teacher education institutions which were selected using cluster sampling technique. TLGPI is an essential instrument to reflect in generating the teaching and learning guiding principles in higher education level in Malaysia. Confirmatory Factor Analysis has validated all 4 items of Quality Learning (QL) construct and also all 4 items of Constructive Alignment (CA) construct of TLGPI whereby all items indicated high reliability and internal consistency. A Confirmatory Factor Analysis also confirmed that a single factor model was used to generate teaching and learning guiding principles.
\end{abstract}

Keywords: Teaching and learning guiding principles; quality learning spaces, resources and technologies; constructive alignment; higher teacher education institution; confirmatory factor analysis

\begin{abstract}
Abstrak
Tujuan kajian ini adalah untuk meneroka kepentingan elemen ruang pembelajaran, sumber dan teknologi yang berkualiti dan penjajaran konstruktif dalam Prinsip Panduan Pengajaran dan Pembelajaran (PPPP). Kajian yang dijalankan dengan menggunakan Instrumen Prinsip Panduan Pengajaran dan Pembelajaran (IPPP) untuk melihat kebolehpercayaan dan kesahan instrumen dalam menjana Prinsip Panduan Pengajaran dan Pembelajaran (PPPP). Peserta terdiri daripada 357 pendidik guru Malaysia daripada sepuluh institusi pendidikan tinggi guru yang dipilih melalui persampelan berkelompok. IPPPP adalah instrumen penting dalam menjana prinsip panduan pengajaran dan pembelajarandi peringkat pengajian tinggi di Malaysia. Analisis Pengesahan Faktor (APF) telah mengesahkan semua 4 item dalam konstruk Kualiti Pembelajaran (KP) dan semua 4 item dalam konstruk Penjajaran Konstruktif (PK) bagi IPPPP di mana semua item menyatakan kebolehpercayaan yang tinggi dan konsisten. APF juga mengesahkan bahawa model faktor tunggal telah digunakan untuk menghasilkan prinsip panduan pengajaran dan pembelajaran.
\end{abstract}

Kata kunci: Prinsip panduan pengajaran dan pembelajaran; ruang pembelajaran, sumber dan teknologi yang berkualiti; penjajaran konstruktif; institusi pengajian tinggi pendidikan guru; analisis pengesahan faktor

(C) 2019 Penerbit UTM Press. All rights reserved

\subsection{BACKGROUND OF THE STUDY}

Teaching and learning guiding principles (TLGP) are based on the National Philosophy of Education, the Philosophy of Teacher Education as well as the National Education Transformation Plan. The principles describe holistic components of the teaching and learning process that reflect the balance of evidence in the research literature on the conditions under which student learning grow. Each principle has a direct bearing on the quality of students' intellectual development and their overall experience of university life and beyond as they embark on a process of lifelong learning. The ultimate objective of teaching and learning programs is to prepare quality teachers for future with distinctive attributes that enable them to contribute to ever-changing global context in a meaningful and positive way (University Education Research Laboratory, 2014). Figure 1 shows the teaching and learning guiding principles. In this study, two of the six themes of TLGP were chosen provide the structure and methodology of institutional teaching and learning excellence which are interrelated and interdependent which are "To provide quality learning spaces, resources and technologies" and "To ensure a constructive alignment between an evolving knowledge base, students learning outcomes, learning experiences, actual practice and assessment”. 


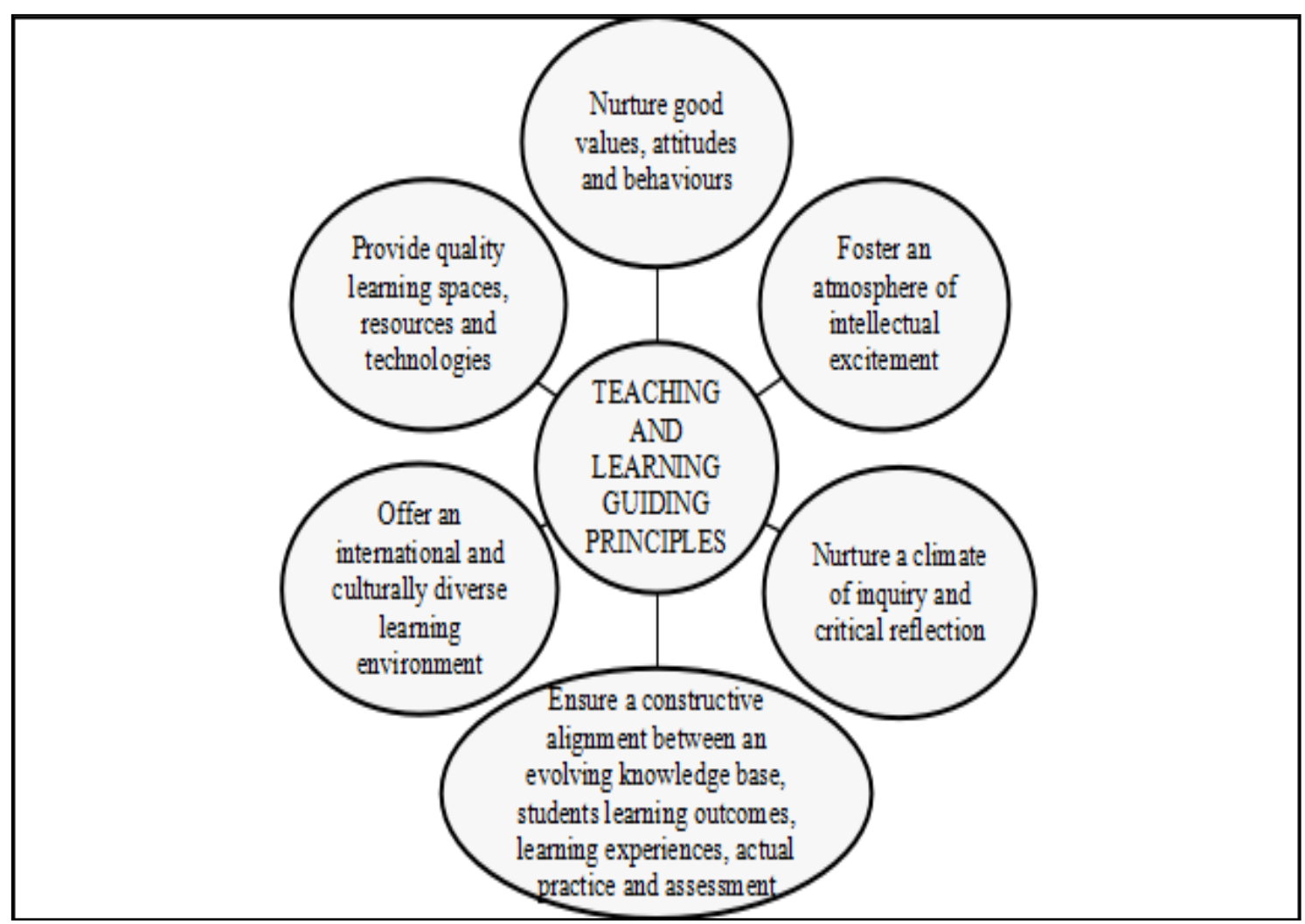

Figure 1 Teaching and learning guiding principle themes

Source: University Education Research Laboratory (UERL), 2014

\subsection{LITERATURE REVIEW}

Quality Learning Spaces, Resources and Technologies

The environment needs to be conducive to learning, allowing the pupils space and time to interact within the learning and teaching process for education in school to be effective. Creating and maintaining stimulating learning environments can be achieved through effective classroom organization, interactive and whole school displays and a climate of innovation.

The researcher considers that quality teaching and learning spaces that encourage and allow a wide range for teaching and learning methods, which accommodate different approaches to teaching and learning across the disciplines, and which have effortlessly integrated electronic technologies. There are certain that developments in technology dramatically enhance the possibilities for conceptualising and designing educational activities. The information and communication technologies are an integral part of the process of knowledge development and increasing in all fields. These technologies afford previously unimaginable learning experiences and can greatly assist in exposing students to the frontiers of knowledge in particular fields. Therefore, develop the skills of independent information searching, evaluation and utilisation using all available sources of information it is important for teachers (Tajudin et al., 2014).

A several points arising from research about conducive learning environment listed by Cacait (2017) are:

a. The best learning environment is one of high challenge and low stress.

b. $\quad$ Ritualised and patterned positive teacher behaviour influences performance.

c. Constant and varied exposure to new material encourages quicker and deeper learning.

d. Differentiated structures are necessary for effective individualised learning.

e. Constant and varied exposure to new material encourages quicker and deeper learning.

f. Music can be used to improve recall as well as create the chosen learning environment.

g. Incorporate a range of teaching strategies within planning.

h. $\quad$ Ensure resources are appropriate, accessible, identifiable and relevant to children's learning needs.

i. Environment should support pupils to become independent and active learners.

j. $\quad$ Adopt a collaborative approach when planning for children's needs.

k. Good visual display can improve recall and attention by up to $80 \%$.

1. Equal opportunities form an integral part of the formal and informal curriculum. 
The flexible teaching and learning spaces that encourage and allow a wide range for teaching and learning methods were also considered. It is accommodate different approaches to teaching and learning across the disciplines, and which have effortlessly integrated electronic technologies. There are no doubt developments in technology dramatically enhance the possibilities for conceptualising and designing educational activities. The information and communication technologies are an essential part of the process of knowledge development and dissemination in all fields. These technologies provide previously unthinkable learning experiences and can greatly assist in revealing students to the frontiers of knowledge in particular fields. Therefore, it is essential for teachers to develop the skills of independent information searching, evaluation and utilization using all available sources of information.

The study by Wong, Goh and Rahmat (2013) has proved that Technology Acceptance Model (TAM) can be applied in a Malaysian context as a measure of technology acceptance among student teachers. It has provided evidence that the items reflect student teachers' intentions to use computers in teaching and learning. Therefore, teacher educators must take an action to involve drastically towards educational technology based activities in their classroom accordance with the country aspiration to produce technology literate citizens in public schools (Wong, Goh, Fahri \& Osman, 2010). For an example, study by Rahman and Masuwai (2014), they were proposed the CDEARA Model in transforming standard lecture to be more interactive and students actively involved in the process of learning.

As a result, quality learning spaces, resources and technologies (QL) element included in other guiding principles institutions' as example Melbourne University, Wichita University and Nottingham University to provide the premium quality for teaching and learning. The QL element respectively embedded in the principle as shown in Table 1.

Table 1 Principles for quality learning

\begin{tabular}{cll}
\hline Study / University & \multicolumn{1}{c}{ Principle } \\
\hline TLGP & $\bullet$ & $\begin{array}{l}\text { Teaching and learning could provide quality learning spaces, resources and } \\
\text { technologies (QL). }\end{array}$ \\
Melbourne University & $\bullet$ & Premium quality learning spaces, resources and technologies. \\
Wichita University & $\bullet$ & Technology Integration. \\
Nottingham University & $\bullet$ & Staff and student support (intellectual, emotional, physical and spiritual well-being).
\end{tabular}

Constructive Alignment between an Evolving Knowledge Base, Students Learning Outcomes, Learning Experiences, Actual Practice and Assessment

The researcher believes that teaching and learning must ensure a constructive alignment between developing knowledge base, student learning outcomes, teaching and learning experiences, activities to bridge knowledge, practice and assessment (Tajudin et al., 2014). Constructive alignment is a balancing between all the elements in teaching and learning for actual practice. As recommended by Butt and Kausar (2010), this is an opportunity for teachers to upgrade their knowledge and to enhance their skills and practices as a new strategies of teaching. Components in constructive alignment element can divided into five components which are evolving:

\section{Knowledge Base}

Organized repository of knowledge (in a computer system or an organization) consisting of concepts, data, objectives, requirements, rules, and specifications. Its form depends on whether it supports an (1) artificial intelligence or expert system based retrieval, or (2) human based retrieval. In the first case, it takes the form of data, design constructs, couplings, and linkages incorporated in a software. In the second case, it takes the form of physical documents and textual information (Business Dictionary, 2016).

\section{Students Learning Outcomes}

Student learning outcomes are statements that specify what students will know, be able to do or be able to demonstrate when they have completed or participated in a program/activity/course/project. Outcomes are usually expressed as knowledge, skills, attitudes or values (Canada College, 2016).

\section{Learning Experiences}

Learning experience refers to any interaction, course, program, or other experience in which learning takes place, whether it occurs in traditional academic settings (schools, classrooms) or nontraditional settings (outside-of-school locations, outdoor environments), or whether it includes traditional educational interactions (students learning from teachers and professors) or nontraditional interactions (students learning through games and interactive software applications) (The Glossary of Education Reform, 2013).

\section{Actual Practice And Assessment}

Taking a cue from Alexander (2001), teaching practices comprise (University of Sussex, 2013):

i- $\quad$ Teacher spoken discourse (including instruction, explanation, metaphor, questioning responding, elaboration and management talk); 
ii- $\quad$ Visual representation (using a chalkboard, writing, diagrams, pictures, textbook, learning aids such as stones, experiments, drama) to understand or construct the new knowledge being presented or indicated to the learners;

iii- $\quad$ The act of setting or providing tasks for learners to cognitively engage with new content or develop physical skills, such as experimentation, reading, writing, drawing, mapping, rehearsing, problem solving, practising;

ivA variety of social interactions, in which language is central between learners or learners and teacher such as pairs, groups, individually or whole - class;

v- Teachers' monitoring, use of feedback, intervention, remediation and formative and summative assessment of the students or assessment by the students themselves.

vi- $\quad$ Assessment - Assessment of student learning is the process by which we ascertain through data collection if students have learned the skills, content, and habits of mind that will make them successful (Tiffin University, 2016).

All the components listed can conclude as how the teachers deliver the knowledge to achieve the learning outcomes for their students that combined the learning experiences by the learners and teaching practices by the teachers that showed through the assessment conducted. This components are very important in providing adequate knowledge that leads to enhanced achievements as well as guidance which improves the motivational aspects to the learners during the instruction. This all about the teacher's role to their learners (Keong, Atan, Majid, Rahman \& Fook, 2013).

As a result, constructive alignment (CA) element included in other guiding principles institutions' like Melbourne University, Griffith University, Eberly Centre of Queensland University, Wichita University, Carroll University and the study by Kanuka (2002) that involved evolving knowledge base, students learning outcomes, learning experiences, actual practice and assessment. The CA element respectively embedded in the principle as shown in Table 2.

Table 2 Principles for constructive alignment

\begin{tabular}{|c|c|}
\hline Study / University & Principle \\
\hline TLGP & $\begin{array}{l}\text { - Teaching and learning could ensure a constructive alignment between an evolving } \\
\text { knowledge base, student learning outcomes, learning experiences, actual practice, and } \\
\text { assessment (CA). }\end{array}$ \\
\hline Wichita University & $\begin{array}{l}\text { - The connection of teaching experiences and assessment. } \\
\text { Understanding content knowledge and pedagogical content knowledge and their alignment } \\
\text { with standards. }\end{array}$ \\
\hline $\begin{array}{l}\text { Eberly Centre of } \\
\text { Queensland University }\end{array}$ & $\begin{array}{l}\text { - Effective teaching involves aligning the three major components of instruction: learning } \\
\text { objectives, assessments, and instructional activities. } \\
\text { - Effective teaching involves articulating explicit expectations regarding learning objectives } \\
\text { and policies. } \\
\text { - Effective teaching involves prioritizing the knowledge and skills we choose to focus on. } \\
\text { Effective teaching involves recognizing and overcoming our expert blind spots. }\end{array}$ \\
\hline Melbourne University & $\begin{array}{l}\text { - } \quad \text { An adaptive curriculum } \\
\text { - } \quad \text { Clear academic expectations and standards. } \\
\text { - } \quad \text { Learning cycles of experimentation, feedback and assessment. }\end{array}$ \\
\hline Griffith University & $\begin{array}{l}\text { - Emphasise the importance, relevance, and integration of theory and knowledge with } \\
\text { professional practice to develop solutions to real world issues. } \\
\text { Enhance student engagement and learning through effective curriculum design, pedagogy } \\
\text { and assessment strategies. }\end{array}$ \\
\hline Carroll University & $\begin{array}{l}\text { - Curricularly Integrative teachers use interdisciplinary curricula to promote student and } \\
\text { experience. }\end{array}$ \\
\hline Kanuka (2002) & - Learning that include an assessment process that is personally meaningful. \\
\hline
\end{tabular}

\subsection{PROBLEM STATEMENT AND RESEARCH OBJECTIVE OF THE STUDY}

A list of guiding principles in redesigning teacher preparation program in University of Toronto was proposed by Fullan (1993). Ragan (1999) described the development of guiding principles as a focus of the true mission of any educational system. Meanwhile, Kennedy (1997) introduced a possible indicator by standards for teacher educators and teacher education programme in defining an ideal reformation to strive for. Ratnavadivel et al., (2014), also in their study to develop Teacher Education Model for Preparing Quality Teachers for the Future (2014 - 2018) had proposed eight provisional guiding principles as a basic teacher education philosophy and aims that frame the qualities desired in teacher education.

Since the guiding principles stressed as a major driver conducting an educational shift, it is strongly recommended that research should be conducted on generating teaching and learning guiding principles in Malaysian Higher Education Institutions (MHEI) as recommended by Fullan (1993); Kennedy (1997); Ragan (1999); Grossman (2009) and Reid (2014) . Such ineffective exemplification of teaching among Malaysian teachers warrants immediate attention and appropriate intervention. Some teacher education programmes are appropriately providing the survival skills but there are lack of training from expertise and without necessary knowledge (DarlingHammond \& Sykes, 2004).

Therefore, it is crucial to review existing teacher education programmes, giving adequate attention, emphasis and focus on the aspect of teaching and learning in the teacher education programmes. This is to enhance and where necessary, to transform their teacher education programmes so that it will be able to produce teachers for the 21 st Century and beyond. As such, this study will form the guiding 
principles for teaching and learning to ensure that appropriate and effective pedagogies are used in the curriculum, with the objective of preparing teachers with the instructional approaches required for effective classroom instruction. Therefore, quality learning spaces, resources and technologies and constructive alignment in education are the main element to focus on with the intention required.

Based on the problem statements, guiding principles is the biggest concern as an action and proposals to transform teaching and learning environment in the higher teacher education institutions. The gap of knowledge about TLGP in Malaysia is an encouragement for need analyses to be conducted in the Malaysian teaching and learning practices. There is a need for research in identifying the elements that are important for teaching and learning. Hence, there is need to understand the classifying of elements for further analyses to generate TLGP for Malaysian Teacher Education Programme (MTEP) with a valid and reliable instrument.

Due to the importance of quality learning spaces, resources and technologies and constructive alignment element in TLGP, this study attempted to assess the QL and CA construct in TLGPI and the items included in this construct based on teacher educator views. Specifically, the research objective of the study were as follows:

1. To assess for model fit and reliability of QL and CA construct in TLGPI using CFA.

2. To assess the convergent validity of the QL and CA construct using CFA.

3. To finalise the items obtained in QL and CA construct in TLGPI.

\subsection{METHODOLOGY}

\section{Research Design}

This study employed a descriptive research design using the survey method as our interest to obtain the teaching and learning guiding principles. Teacher educators responded to the survey to gather information about what local teacher educators think are important in teaching and learning.

\section{Data Analysis}

The Confirmatory Factor Analysis (CFA) was used to examine the underlying factor structure of the data. According to Schumacker and Lomax (1996); Wang and Ahmed (2004); and Byrne (2013), CFA is suppose as a best-known statistical procedure for testing a hypothesized factor structure. CFA also known as a measurement model in Structural Equation Modeling(SEM). SEM is one of the most establish and popular multivariate analysis which combines factor and path analysis, allowing investigation of various exogenous and endogenous variables (Ho, 2006).

Hair et al. (2010) suggested six stages to ascertain that the theory fits the obtained data. The stages are: (1) Defining individual constructs; (2) Developing the measurement model; (3) Designing a study to produce empirical result; (4) Assessing the measurement model validity; (5) Specifying the structural model; and (6) Assessing the structural model validity. For this study, there are only four stages involved because no structural model develops since the study only involved exogenous variables. One of the research objectives is to test the overall model fit between the proposed research model and the obtained data of the important of TLGP. The proposed research model tested is the conceptual framework of this study.

\section{Sample}

The population in this study were teacher educators in all Public Universities (PU) and Teacher Training Institutions (TTI) in Malaysia that offer Teacher Education Programmes. There are 6087 number of population was obtained and the minimum sample size required for this study according to Cochran (1977) is 255.

A total of 357 of teacher educators from ten public universities (PU) and teacher training institutions (TTI) in Malaysia were selected to be participated in this study. They were selected based on cluster sampling. Malaysia was divided into five zones which are Northern, Southern, Western, Central/Eastern, Southern and Sabah/Sarawak zone. Each zone was then calculated to the proportion number of teacher educators in PU and TTI. Number of sample required in each zone was calculated. This step followed by cluster sampling to randomly select the PU and TTI in each zone as shown in Table 3. The mailed survey administered to the samples.

Table 3 List of institutions selected with number of respondents

\begin{tabular}{lccccc}
\hline Zone & $\begin{array}{c}\text { Type of } \\
\text { Institutions }\end{array}$ & $\begin{array}{c}\text { Number of } \\
\text { Teacher } \\
\text { Educators }\end{array}$ & $\begin{array}{c}\text { Total Number } \\
\text { of Teacher } \\
\text { Educators in } \\
\text { each Zone }\end{array}$ & $\begin{array}{c}\text { Minimum } \\
\text { Sample } \\
\text { Required }\end{array}$ & $\begin{array}{c}\text { Number of } \\
\text { Sample (after } \\
\text { 40\% addition) }\end{array}$ \\
\hline Northern & TTI1 & 178 & 246 & 70 & 98 \\
Western & PU1 & 68 & & & 45 \\
& TTI2 & 217 & 415 & 32 & 70 \\
Central & TT13 & 198 & 219 & 50 & \\
& TTI4 & 140 & & & 74 \\
Southern & PU2 & 79 & 262 & 53 &
\end{tabular}




\begin{tabular}{lccccc} 
Sabah/ & TTI6 & 157 & 236 & 50 & 70 \\
Sarawak & PU4 & 79 & & & \\
Total & $\mathbf{1 0}$ & $\mathbf{1 3 7 8}$ & $\mathbf{1 3 7 8}$ & $\mathbf{2 5 5}$ & $\mathbf{3 5 7}$ \\
\hline
\end{tabular}

\section{Demographic information}

The respondents' general demographic information are presented in Table 4. There were 355 teacher educators participated in this study, where $184(51.8 \%)$ of them were male teacher educators and $171(48.2 \%)$ were female. This shows almost an equal number of male and female educators involved in this study with a slight large number of male teacher educators. There were $9 \%$ experienced teacher educators with more than 30 years of teaching experience. $30.3 \%$ were doctorate holder while $62.5 \%$ are master's degree holders. About $0.3 \%$ of the respondents completed their associated professor while only a very small percentage of them (1.4\%) are professors.

Almost all $(86.2 \%)$ of teacher educators in this study have major expertise in education. Only $13.8 \%$ of them are minor expertise in education. They were teaching an education courses for variety of disciplines in Mathematics Education, Science Education, Early Learning Child Education, Physical Education, Moral Education, English Language, Islamic Education, Curriculum, Education Technology, Arabic Language, Music Education, Measurement, Education Evaluation, Psychology, Social Research, Vocational Education, Visual Art Telecommunication, Sport Education, Counseling and University Courses. In regards of the official position held, a large majority of $99.7 \%$ of them were ordinary lecturers who are subject lecturers and not holding higher posts. Only $0.3 \%$ of the studied teacher educators are tutor.

Table 4 Demographic Information

\begin{tabular}{|c|c|c|c|}
\hline & Variable & Frequency & Percentage \% \\
\hline \multirow[t]{2}{*}{ Position } & Lecturer & 354 & 99.7 \\
\hline & Tutor & 1 & 0.3 \\
\hline \multirow[t]{6}{*}{ Designation } & Professor & 5 & 1.4 \\
\hline & Associate Professor & 1 & 0.3 \\
\hline & Doctor & 77 & 21.7 \\
\hline & Miss & 9 & 2.5 \\
\hline & $\mathrm{Mr}$ & 149 & 42.0 \\
\hline & Mrs & 114 & 31.8 \\
\hline \multirow[t]{11}{*}{ Institution } & TTI 3 & 47 & 13.2 \\
\hline & TTI 2 & 31 & 8.7 \\
\hline & TTI 4 & 40 & 11.3 \\
\hline & TTI 1 & 49 & 13.8 \\
\hline & TTI 5 & 21 & 5.9 \\
\hline & TTI 6 & 60 & 16.9 \\
\hline & PU 4 & 15 & 4.2 \\
\hline & PU 2 & 44 & 12.4 \\
\hline & PU 1 & 18 & 5.1 \\
\hline & PU 3 & 30 & 8.5 \\
\hline & Variable & Frequency & Percentage \% \\
\hline \multirow[t]{6}{*}{ Teaching Experience } & $<1$ year & 6 & 1.7 \\
\hline & $1-5$ years & 26 & 7.3 \\
\hline & 6-10 & 49 & 13.8 \\
\hline & $11-15$ & 52 & 14.6 \\
\hline & $16-20$ & 62 & 17.5 \\
\hline & $21-30$ & 128 & 36.1 \\
\hline \multirow[t]{2}{*}{ Gender } & Male & 184 & 51.8 \\
\hline & Female & 171 & 48.2 \\
\hline \multirow[t]{7}{*}{ Academic Qualification } & SPM/MCE & 0 & 0 \\
\hline & STPM & 0 & 0 \\
\hline & Diploma & 0 & 0 \\
\hline & Bachelor & 24 & 6.8 \\
\hline & Master & 222 & 62.5 \\
\hline & Doctor of Philosophy & 108 & 30.4 \\
\hline & Others & 1 & 0.3 \\
\hline \multirow{5}{*}{$\begin{array}{l}\text { Professional } \\
\text { Qualification }\end{array}$} & Bachelor of Education & 137 & 38.6 \\
\hline & Diploma in Education & 89 & 25.1 \\
\hline & Teacher's Certificate & 78 & 22.0 \\
\hline & Advanced Diploma & 2 & 0.6 \\
\hline & Others & 49 & 13.8 \\
\hline
\end{tabular}




\section{Instrumentation}

A set of 5-point Likert scale (ranging from 1 = "not at all important" and "5 - "extremely important") instrument, namely the Teaching and Learning Guiding Principles Instrument (TLGPI) was administered to the samples. The samples were required to response to the 44 items which may address an early indication of the importance of each domain to establish teaching and learning guiding principles.

The instrument comprised of six themes as shown in Table 5 that obtained from the related literature to generating the items from. There were eight items to assess teaching and learning should foster an atmosphere of intellectual excitement (Theme 1); the following eight items to assess the teaching and learning should provide quality learning spaces, resources and technologies (Theme 2); the next five items to assess the teaching and learning should ensure a constructive alignment between an evolving knowledge base, students learning outcomes, learning experiences, actual practice and assessment (Theme 3); seven items to assess the teaching and learning should offer an international and culturally diverse learning environment (Theme 4); three items to assess the teaching and learning should nurture a climate of inquiry and critical reflection (Theme 5); and the last seven items to assess the teaching and learning should nurture good values, attitude and behaviors (Theme 6).

Followed by the normality and outliers test whereas 6 items were deleted to fulfill the recommendation values. Finally, only 38 items and were used for the analysis as shown in Table 5. There only two themes measure in this study which are QL and CA constructs. Table 5 show the mean and standard deviation for QL construct are 4.23 and 0.77. Meanwhile, the mean and standard deviation for CA construct are 4.48 and 0.62 . These results indicated that CA and QL constructs both are among the most important theme chosen by the respondents. These two constructs are related each other and strongly chosen for this study.

Table 5 Set of Items in Teaching and Learning Guiding Principles Instruments (TLGPI)

\begin{tabular}{|c|c|c|c|c|}
\hline Theme & Name of construct & Number of item & Mean & Standard Deviation \\
\hline 1 & $\begin{array}{l}\text { Intellectual excitement } \\
\text { (IE) }\end{array}$ & 8 items & 4.24 & 0.76 \\
\hline 2 & $\begin{array}{l}\text { Quality learning spaces, resources and technologies } \\
\text { (QL) }\end{array}$ & 8 items & 4.23 & 0.77 \\
\hline 3 & $\begin{array}{l}\text { Constructive alignment between an evolving knowledge } \\
\text { base, students learning outcomes, learning experiences, } \\
\text { actual practice and assessment } \\
\text { (CA) }\end{array}$ & 5 items & 4.48 & 0.62 \\
\hline 4 & $\begin{array}{l}\text { International and culturally diverse learning environment } \\
\text { (IC) }\end{array}$ & 7 items & 4.02 & 0.93 \\
\hline 5 & $\begin{array}{l}\text { Climate of inquiry and critical reflection } \\
\text { (CI) }\end{array}$ & 3 items & 4.40 & 0.70 \\
\hline 6 & $\begin{array}{l}\text { Nurture good values, attitude and behaviours } \\
\qquad(\mathrm{NV})\end{array}$ & 7 items & 4.59 & 0.87 \\
\hline Total & 6 & 38 items & 3.56 & 0.78 \\
\hline
\end{tabular}

\subsection{RESULTS AND DISCUSSION}

QL construct as a latent variable with seven observed variables and CA construct with five observed variables were measured on the instrument. Figure 2 and 3 shows the measurement model for QL and CA construct. The measurement model will assess the degree and numbers of indicators representing a measured construct through CFA. The CFA was tested for model fit, reliability and construct validity of the construct measured. To examine the model fit of this study, the CFA encompassed four indices namely TLI $>0.90$, CFI $>0.90$, RMSEA $<0.08$ and Chisq $/ \mathrm{df}<5.0$ and the factor loading should be above 0.5 . 


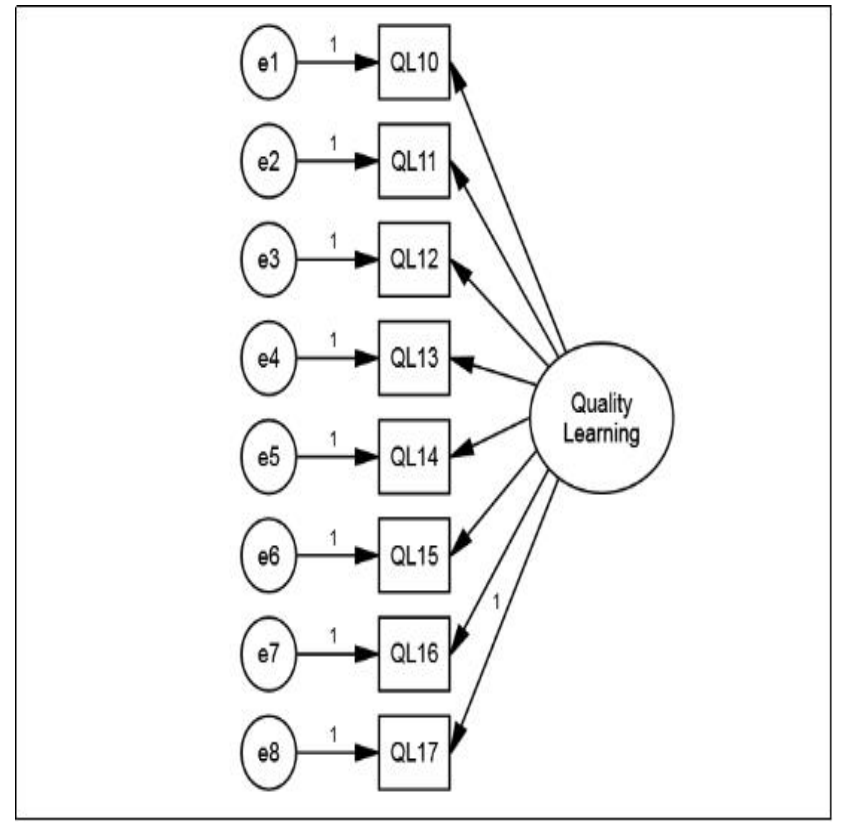

Figure 2 Measurement model for quality learning

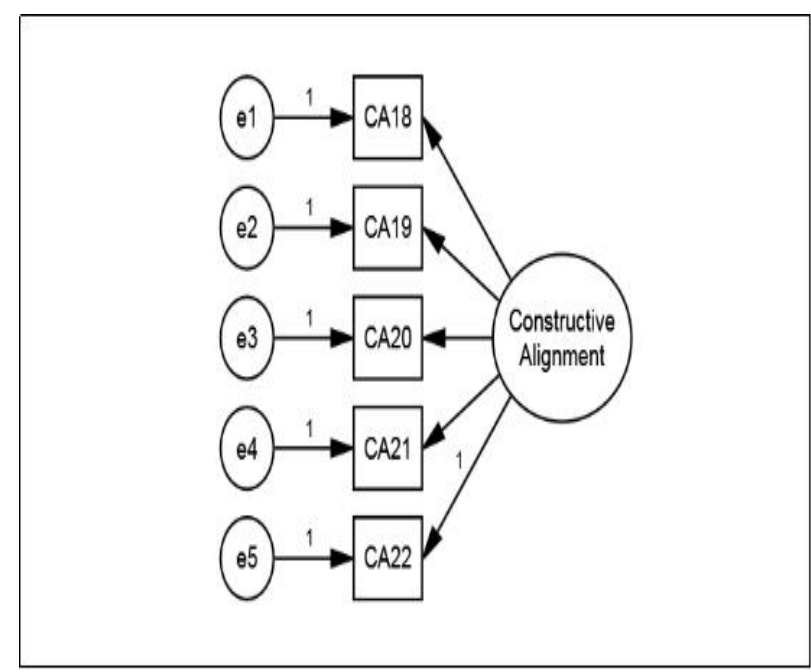

Figure 3 Measurement model for constructive alignment

\section{Objective 1: To assess for model fit and reliability of QL and CA construct in TLGPI using CFA.}

Figure 4 presents the initial CFA for quality learning (QL) which consisted of eight items. The analysis showed poor fit (TLI=0.83, $\mathrm{CFI}=0.88$, RMSEA=0.16 and Chisq/df=9.86) even though all factor loadings are more than 0.5 . Therefore, the researcher removed the items QL12, QL13, QL14 and QL15 one by one. Then, the researcher correlated the items QL10 with QL11 (23.934) in order to improve the fit according to the modification indices.

Four items were dropped according modification indices which are QL12 (I inform students where they can obtain the books and materials needed for the course (e.g. library, internet, website etc); QL13 (I encourage students to use the technological equipment provided for learning purposes during my lessons); QL14 (I use web-based tools to manage my course); and QL15 (I assign tasks that include the use of web-based tools). All the items were described about how to manage the class with a technology application that is not really connected with the principle of quality learning spaces, resources and technologies. Otherwise, item QL10 (I check the technological equipment before I start my lessons) and QL11 (I upload the course outline or instructional plan online before the course begins) were correlated because it were related each other in the process of teaching preparation by the teacher before the class started.

The revised model (Figure 5) with four items surpassed all the criterion values (TLI=0.94, CFI=0.99, RMSEA=0.11 and Chisq/df=5.20) and showed better fit with the data. The RMSEA (0.11) closed to 0.1 and Chisq/df (5.20) almost near to 5.0. In some cases, they were more than 5.0 of Chisq/df value depending on sample size and response rate. Eventhough, for initial CFA for QL, Chisq/df value was beyond 5.0 as suggested by Marsh \& Hocevar (1985) indicating satisfactory of fit indices as illustrated in Table 6 . However, to prove the model satisfied the fit indices, we can refer to the fact that RMSEA and Chisq/df is near the recommended value and other fit indices (TLI, CFI) of the model offered good fit.

Table 6 Fit Indices of the revised CFA for quality learning

\begin{tabular}{cccc}
\hline Fit Indices & Index Value & Recommended Value & Results \\
\hline TLI & 0.94 & $>0.90$ & Good Fit \\
CFI & 0.99 & $>0.90$ & Good Fit \\
RMSEA & 0.11 & $<0.10$ & Good Fit \\
Chisq/df & 5.20 & $<5.00$ & Good Fit \\
\hline
\end{tabular}




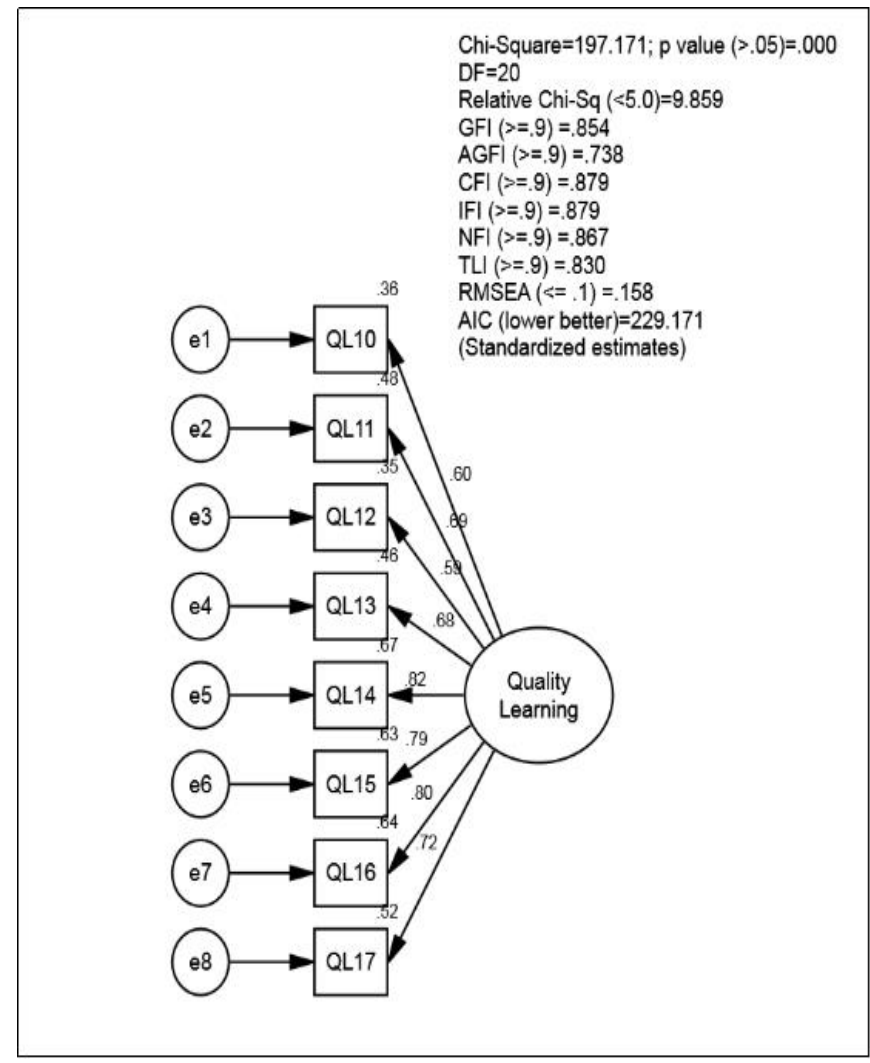

Figure 4 The initial CFA for quality learning

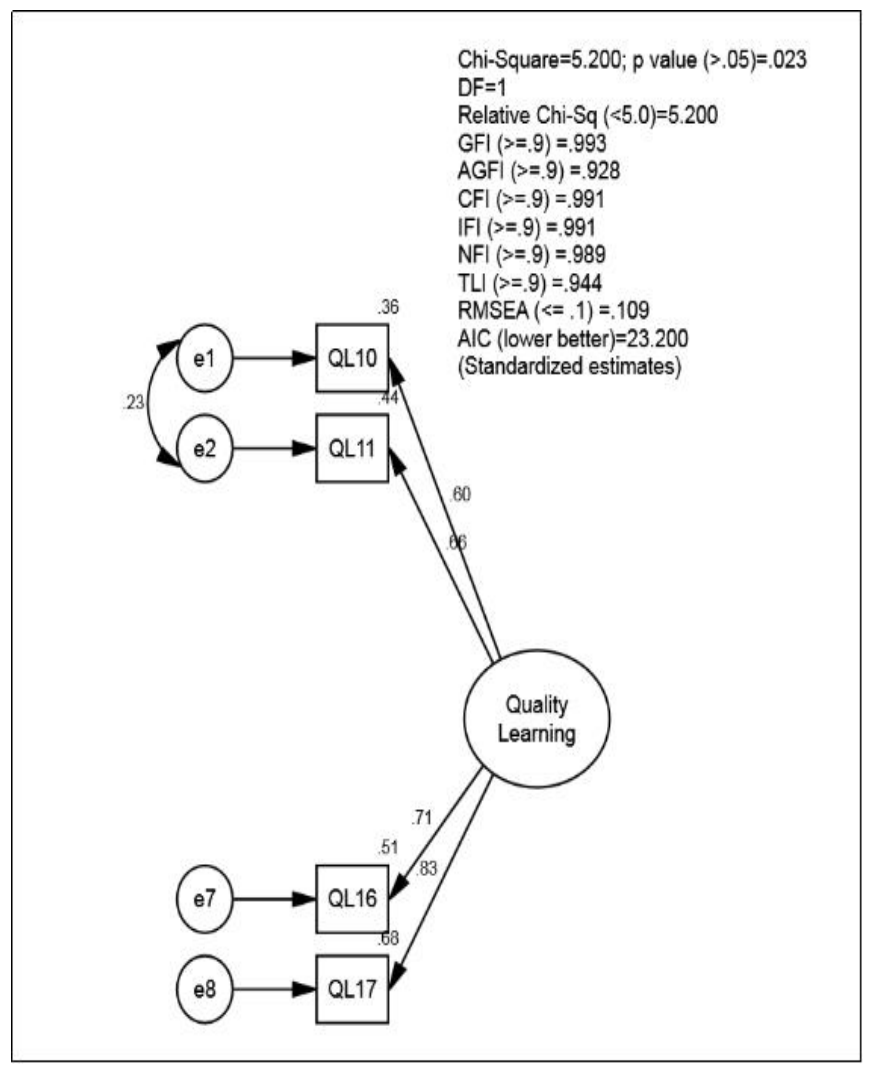

Figure 5 The revised CFA for quality learning

The initial CFA for Constructive Alignment construct which consisted of five items (Figure 6) gained a poor fit (RMSEA=0.17, $\mathrm{SRMR}=, \mathrm{TLI}=0.84$ and Chisq/df=11.74). In order to improve the model fit, the items CA19 (I use the set learning outcomes for students as guidance in planning the teaching content and activities for each lesson) was dropped according to the modification indices. This item was released becaused it is more to the preparation of teaching and not keen to the alignment of knowledge and learning outcomes for student. The teaching content had been arranged and teacher only need to deliver it with the certain activities to achieve the learning outcomes required. By adapting school curricula and teaching strategies, teachers can provide learning activities and practical experiences to students according to their abilities and needs (Education Bereau, 2016).

The revised model after dropping of the indicator, met the model fit (Figure 7). All four items surpassed all the criterion values $(\mathrm{TLI}=0.99, \mathrm{CFI}=1.00, \mathrm{RMSEA}=0.015$ and Chisq/df=1.076) and showed better fit with the data (Table 7).

Table 7 Fit indices of the revised CFA for constructive alignment

\begin{tabular}{cccc}
\hline Fit Indices & Index Value & Recommended Value & Results \\
\hline TLI & 0.999 & $>0.90$ & Good Fit \\
CFI & 1.000 & $>0.90$ & Good Fit \\
RMSEA & 0.015 & $<0.10$ & Good Fit \\
Chisq/df & 1.076 & $<5.00$ & Good Fit \\
\hline
\end{tabular}




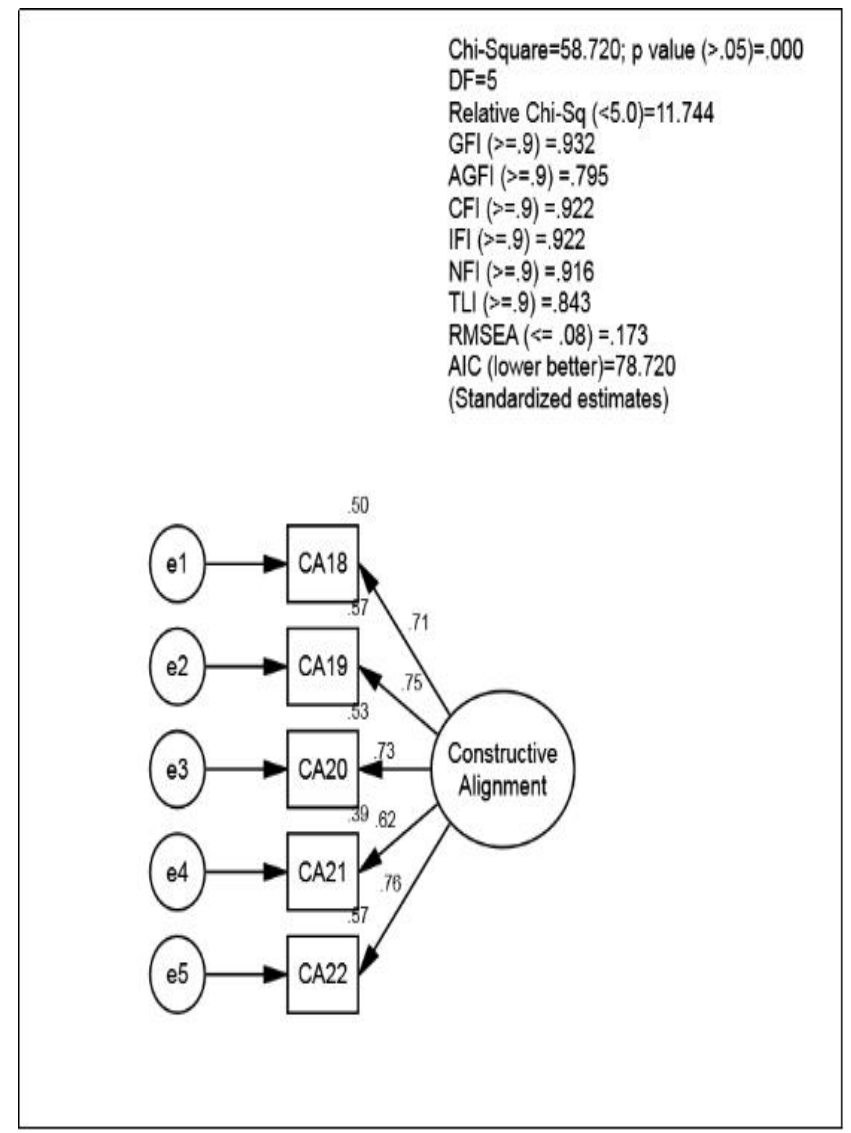

Figure 6 The initial CFA for constructive alignment

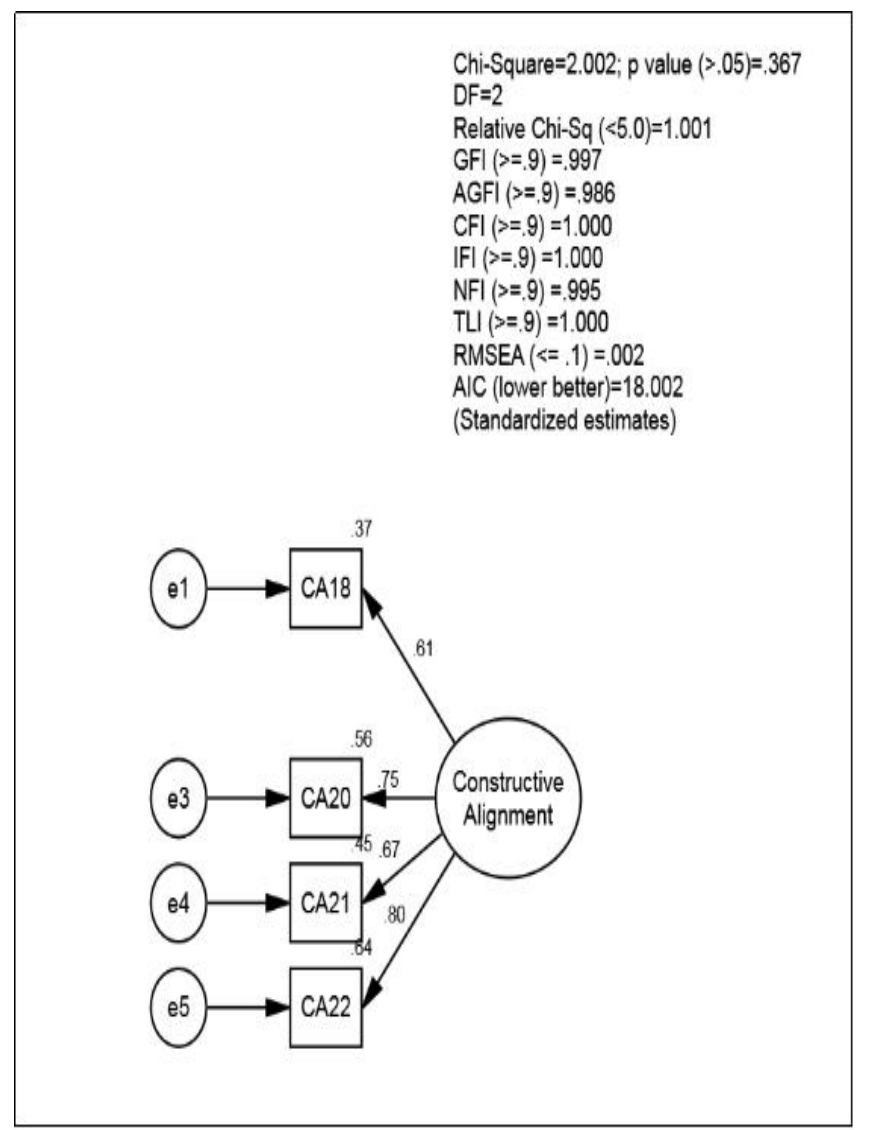

Figure 7 The revised CFA for constructive alignment

\section{Objective 2: To assess the convergent validity of $Q L$ and CA construct in TLGPI using CFA.}

Convergent validity is achieved when all items in a measurement model are statistically significant. The convergent validity could be verified by computing the Average Variance Extracted (AVE) for every construct (Awang, 2014). The AVE (0.57), measured exceeded 0.5 and CR (0.83) larger than 0.6 indicating satisfactory validity and reliability (Fornell \& Larcker, 1981; Bryne, 2010). Furthermore, all items of QL construct achieved high factor loadings which above $\geq 0.5$ (Hair et al., 2010) as showed in Table 8 . This is an evidence of convergent validity of the construct indicated that the items could measure the same trait.

Table 8 Factor Loading, Average Variance Extracted (AVE) and Construct Reliability (CR) of Quality Learning (QL)

\begin{tabular}{cccc}
\hline Item & Factor Loading & AVE (>0.5) & CR (>0.6) \\
\hline QL10 & 0.60 & 0.75 & 0.81 \\
QL11 & 0.66 & & \\
QL16 & 0.71 & & \\
QL17 & 0.83 & & \\
\hline
\end{tabular}

Meanwhile, all the factor loadings of items in CA construct in the revised model were above 0.50 and the value for AVE exceeded 0.5 which was 0.5 indicating convergent validity. In addition, the CR value is $0.79(>0.6)$ suggested adequate reliability (Table 9$)$. This is an evidence of convergent validity of the construct.

Table 9 Factor Loading, Average Variance Extracted (AVE) and Construct Reliability (CR) of Constructive Alignment (CA)

\begin{tabular}{cccc}
\hline Item & Factor Loading & AVE $(>\mathbf{0 . 5})$ & CR $(>\mathbf{0 . 6})$ \\
\hline CA18 & 0.60 & 0.50 & 0.79 \\
CA20 & 0.75 & & \\
CA21 & 0.67 & & \\
CA22 & 0.80 & & \\
\hline
\end{tabular}


Objective 3: To finalise the items obtained in QL and CA construct in TLGPI.

The analysis has yielded four items of Quality Learning (QL) construct. QL12, QL13, QL14 and QL15 were deleted and finally four items in QL construct as shown in Table 10. This items later retained in IC construct for the final instrument of TLGPI.

Table 10 Final Items of Quality Learning (QL) construct

\begin{tabular}{cl}
\hline Item & $\begin{array}{l}\text { I check the technological equipment before I start my lessons. } \\
\text { Saya memeriksa peralatan teknologi sebelum saya memulakan pelajaran. }\end{array}$ \\
\hline QL11 & $\begin{array}{l}\text { I upload the course outline or instructional plan online before the course begins. } \\
\text { Saya memuat naik rangka kursus atau rancangan instruksional secara atas talian sebelum kursus bermula. }\end{array}$ \\
QL16 & $\begin{array}{l}\text { I include web-based resources in the materials for independent student learning. } \\
\text { QL17 menggunakan sumber berasaskan web sebagai sebahagian daripada bahan pembelajaran kendiri pelajar. }\end{array}$ \\
& $\begin{array}{l}\text { I assist students in developing the skills in using learning resources. } \\
\text { Saya membantu pelajar dalam membangunkan kemahiran menggunakan sumber pembelajaran. }\end{array}$
\end{tabular}

Otherwise, the analysis also has yielded four items of Constructive Alignment (CA) construct. CA19 was dropped and finally four items in CA construct as shown in Table 11. This items also later retained in CA construct for the final instrument of TLGPI.

Table 11 Final Items of Constructive Alignment (CA) Construct

\begin{tabular}{|c|c|}
\hline Item & \\
\hline CA18 & $\begin{array}{l}\text { I relate new content to previously learnt content. } \\
\text { Saya mengaitkan kandungan baharu dengan kandungan yang dipelajari sebelum ini. }\end{array}$ \\
\hline CA20 & $\begin{array}{l}\text { I ask questions that are open and reflective in nature. } \\
\text { Saya bertanya soalan yang terbuka dan reflektif secara semula jadi. }\end{array}$ \\
\hline CA21 & $\begin{array}{l}\text { I prepare experiments or investigative assignments for relevant topics. } \\
\text { Saya menyediakan eksperimen atau tugasan penyiasatan untuk topik-topik yang relevan. }\end{array}$ \\
\hline CA22 & $\begin{array}{l}\text { I ensure that the content and activities for each lesson are appropriate to the topic of the lesson. } \\
\text { Saya memastikan bahawa kandungan dan aktiviti untuk setiap pelajaran sesuai dengan topik pelajaran. }\end{array}$ \\
\hline
\end{tabular}

Developments in technology are integrated with the process of knowledge development. Teacher educators need to flexible in their teaching method and strategies with the electronic technologies (Nottingham University, UK). Provide the best quality learning spaces, resources and technologies is the feat to emerge the aspiration (Melbourne University). Therefore, quality learning (QL) construct give an idea with four items like "I upload the course outline or instructional plan online before the course begins" (QL11) and "I assist students in developing the skills in using learning resources" (QL17).

Professional development as a priority of learning needs for students (Carroll University, Australia; Wichita State University, USA; Griffith University, Australia). It is something to be emphasized in providing students' aim as a learner. Constructive alignment (CA) construct with four items give a guides how to align the curriculum, teaching pedagogies and assessment like "I prepare experiments or investigate assignments for relevant topics" (CA21) and "I ensure that the content and activities for each lesson are appropriate to the topic of the lesson" (CA22).

Eventually, goodness of fit indices of CFA indicated a good fit of the collected data and the model. This specified that the QL and CA construct are acceptable as an important elements in teaching and learning which is based on the requirement (Hair, 2010). Significantly, quality learning spaces, resources and technologies and also constructive alignment between an evolving knowledge base, students learning outcomes, learning experiences, actual practice and assessment as part of TLGP cannot be ignored as combined of the substantial elements in teaching and learning. Nevertheless, the results also shown an empirical evidence of the reliability and validity of TLGPI.

\subsection{CONCLUSION AND IMPLICATION}

This study provides an indication for the evidence of the important of quality learning spaces, resources and technologies and constructive alignment between an evolving knowledge base, students learning outcomes, learning experiences, actual practice and assessment in teaching and learning are part of the principle in TLGP that based on continuous improvement on empirical evidence grounded in the 
context of actual practice. Theoretically, all variables which are specifically and carefully selected based on literatures. Quality learning, resources and technologies (QL) construct itself comes from technology integration concept whereas the developments in technology are integrated with the process of knowledge development. Teacher educators need to flexible in their teaching method and strategies with the electronic technologies.

Based on the findings, teachers might be able to embed quality learning spaces, resources and technologies and constructive alignment element in their teaching and learning practices in higher education as a good proposal according to the views of teacher educators in Malaysia. Higher education institutions need to integrate TLGP into teaching whether for student teacher or teacher educator dimension in assisting the process to produce a quality teacher. Practically, it can provide productive ways and means for teacher educators and policy makers to embed the TLGP in the policies or instructional plan of the courses especially in teacher education programmes in Malaysia. Attend to emphasize the good values, attitudes and behaviours which have greater weights and strength on the developing students' values, attitudes and behaviours as a foundation; there are also a guidance for professional development on how to align the curriculum, teaching pedagogies and assessment for learners.

The present study can be extended to different settings and sample in order to achieve a better measurement model. It is hoped that by validating the TLGPI, then more upcoming related issues will be conducted in the future in order to facilitate teaching and learning practices. It is also can give an important implication to the various stakeholders in higher education institutions (Masuwai, Tajudin, Saad, 2016). However, by considering triangulation in the current methodology, it gives more support in terms of measurement and evaluation of the element.

\section{Acknowledgement}

We extend our gratitude to Ministry of Education Malaysia for providing the funds under the Niche Research Grant Scheme (NRGS): 2014-0001-107-82-2 Sultan Idris Education University for providing the official approval that enables us to do the research. Special thanks to the teacher educator from public universities and teacher training institutions in Malaysia for the involvement in this research.

\section{References}

A. Masuwai, N. M. Tajudin, N. S. Saad, (2016). Evaluating the face and content validity of a Teaching and Learning Guiding Principles Instrument (TLGPI): A Perspective Study of Malaysian Teacher Educators. Malaysian Journal Society and Space. 12(3), 11-21.

B. Business Dictionary. (2016). "Knowledge Base". Retrieved on $8^{\text {th }}$ August 2016 from http://www.businessdictionary.com/definition/knowledge-base.html.

C. B. M. Byrne, (2001). Structural equation modeling with AMOS: Basic Concepts, Applications, And Programming. Erlbaum, Mahwah, NJ.

Canada College. (2016). A Guide To Be A Measurable Student Learning Outcome. Retrieved on $8^{\text {th }}$ August 2016 from https://www.canadacollege.edu/inside/research/slos/documents/STUDENT\%20SERVICES\%20SLO\%20GUIDE\%20BOOK.pdf.

Carroll University. (2014) Teacher education program guiding principles. Retrieved on $7^{\text {th }}$ October 2015 from http://www.carrollu.edu/programs/education/documents/tep_program_guidingprinciples.pdf.

C. Fornell, D. F. Larcker, (1981). Evaluating Structural Equation Models with Unobservable Variables and Measurement Error. Journal of Marketing Research, 18(1), 41-54.

C. L Wang, P. K. Ahmed, (2004). The Development And Validation Of The Organisational Innovativeness Construct Using Confirmatory Factor Analysis. European Journal of Innovation Management, 7(4), 303-313.

Eberly Centre (2015) - Carnegie Mellon University. Principles Of Teaching. Retrieved on $7^{\text {th }}$ October 2015 from https://www.cmu.edu/teaching/principles/teaching.html

Education Glossary. (2013). Retrieved on $8^{\text {th }}$ August 2016 from http://edglossary.org/learning-experience/

F. K. Keong, H. Atan, F. S. Fook, G. T. B. Sai, O. Majid \& Z. A. Rahman. (2013). The Effects of the Pedagogical Agent's Instructional Role on Achievement and Motivation among Students with Different Cognitive Styles. Malaysian Journal of Distance Education, 15(1): 73-87.

Griffith University. (2014) Principles To Promote Excellence In Learning And Teaching Practices at Griffith University. Retrieved on $7^{\text {th }}$ October 2015 from http:// www.griffith.edu.au/_data/assets/pdf_file/0006/.../PrinciplesLandT.pdf

H. Kanuka, (2002). "Guiding Principles For Facilitating Higher Levels Of Web-Based Distance Teaching And Learning In Post-Secondary Settings". Distance Education, 23(2): 163-182.

H. W. Marsh \& D. Hocevar, (1985). Application of Confirmatory Factor Analysis To The Study Of Self-Concept: First-And Higher Order Factor Models And Their Invariance Across Groups. Psychological Bulletin, 97(3), 562.

J. F. Hair, R. E. Anderson, R. L. Tatham, W. C. Black, (2010). Multivariate Data Analysis, 7th ed. Prentice-Hall, New Jersey.

K. T. Wong, \& P. S. C. Goh, Hafizul Fahri, \& Rosma Osman (2010). Computer Attitudes And Use Among Novice Teachers: The Moderating Effects Of School Environment. Malaysian Journal of Learning and Instruction, 7, 93-112.

K. T. Wong, \& P. S. C. Goh, \& M. K. Rahmat. (2013). Understanding Student Teachers' Behavioural Intention to Use Technology: Technology Acceptance Model (TAM) Validation and Testing. Online Submission, 6(1), 89-104.

L. C. Ragan, (1999). Good Teaching Is Good Teaching - An Emerging Set Of Guiding Principles And Practices For The Design And Development Of Distance Education. Cause/Effect, 22(1): 20-24.

L. Darling-Hammond, G. Sykes, (2004). A Teacher Supply Policy for Education: How to Meet the "Highly Qualified Teacher" Challenge. Who's in Charge Here, 164-227.

L. Reid, (2014). Narrative exchanges. London: Routledge.

M. Butt \& S. Kausar. (2010). "A Comparative Study Of Using Differentiated Instructions Of Public And Private School Teacher". Malaysian Journal of Distance Education, 12(1): 105-124.

M. G. Fullan, (1993). Why Teachers Must Become Change Agents. Educational Leadership, 50(6), 12-17.

M. M. Kennedy, (1997). Defining an Ideal Teacher Education Program. Washington, DC: National Council for the Accreditation of Teacher Education.

N. A. Rahman \& A. Masuwai, (2014). Transforming the Standard Lecture into an Interactive Lecture: The CDEARA Model. International Journal for Innovation Education and Research (IJIER), 2(10), 158-168.

N. M. Tajudin, N. A. Rahman, A. Masuwai, N. Idris, (2014). Comparison between Teaching Practices Based on Teacher Educators' Perception and Learning Experiences Based on Student Teachers' Perception at Higher Education Institution. Research Journal in Organizational Psychology and Educational Studies (RJOPES), 3(6), 437-445.

N. Ratnavadivel, C. L. Hoon, M. Salih, J. Low, N. Karuppiah, A. Omar, S. M. Yassin, A. H. Dawi, N. S. Saad, A. T. M. Hashim, (2014). Curriculum Framework For Preparing Quality Teachers For The Future: Developing Guiding Principles. Teacher Education, 4(2), 32-44. 
R. A. Cacait, (2017). Conducive Learning Environment. Retrieved on $6^{\text {th }}$ August 2017 from https://www.scribd.com/document/137653236/Conducive-LearningEnvironment

R. E. Schumacker and R. G. Lomax. (1996). A Beginner's Guide To Structural Equation Modeling. Psychology Press.

R. Ho. (2006). Handbook of Univariate And Multivariate Data Analysis And Interpretation with SPSS. New York: CRC Press.

R. L. Grossman, (2009). The Case For Cloud Computing. IT Professional, 11(2): 23-27.

The University of Nottingham. (2015) Organisation of Teaching. Retrieved on $7^{\text {th }}$ October 2015 from http:// www.nottingham.ac.uk/.../universityofnottinghamstrategicplan2010-15.

Tiffin University. (2016) Assessment. Retrieved on $8^{\text {th }}$ August 2016 from https://www.tiffin.edu/academics/assessment/about/Def._Assessment.pdf.

University Education Research Laboratory. (2014). Sultan Idris Education University. Retrieved on $12^{\text {th }}$ May 2015 from http://www.uerl.upsi.edu.my/.

University of Melbourne. (2007). Nine Principles Guiding Teaching And Learning. Retrieved on $7^{\text {th }}$ October 2015 from http://www.cshe.unimelb.edu.au/resources_teach/framework_teach/docs/9principles.pdf.

University of Sussex. (2013). Pedagogy, Curriculum, Teaching Practices And Teacher Education In Developing Countries. Retrieved on $8^{\text {th }}$ August 2016 from https://eppi.ioe.ac.uk/cms/Portals/0/PDF\%20reviews\%20and\%20summaries/Pedagogy\%202013\%20Westbrook\%20report.pdf?ver=2014-04-24-121331867

Wichita State (2015) University. Teacher Education Student Handbook. Retrieved

on

$7^{\text {th }}$

October 